JURNAL KETAHANAN NASIONAL

P-ISSN: 0853-9340, e-ISSN: 2527-9688

Online sejak 28 Desember 2015 di: http://jurnal.ugm.ac.id/JKN

VOLUME 22

No. 2, 25 Agustus 2016

Halaman 137-157

\title{
PARTISIPASI PEMUDA DALAM MENGEMBANGKAN PARIWISATA BERBASIS MASYARAKAT UNTUK MENINGKATKAN KETAHANAN SOSIAL BUDAYA WILAYAH \\ (Studi di Desa Wisata Pentingsari, Umbulharjo, Cangkringan, Sleman, D.I. Yogyakarta)
}

\author{
Gina Lestari \\ Mahasiswa Program Studi Ketahanan Nasional \\ email: ginalestari0907334@gmail.com
}

Armaidy Armawi

Fakultas Filsafat UGM

Muhamad

Sekolah Pascasarjana UGM

\begin{abstract}
The global tourism waved lead to a new trend of village tourism where tourists came in small groups to interacted and learned the life of villagers intensively. If the management was not well planned, this model inflicted the social cultural changes in society. This study aimed to assessed and formulated the youth participation in the community-based tourism (CBT) development and their contribution on the social cultural resilience of region. This study used descriptive mixed methods research by using quantitative and qualitative approaches. The samples determined through purposive sampling by judgment sampling criteria.

The result showed that youth was the part of the CBT's manager actor in Pentingsari Tourism Village (Dewi Peri). The level of youth participation was a citizen power with an average of 70\%. CBT development allowed the entire community to be actively involved as the main actor. Youth participation in the development of CBT contributed to the social cultural resilience of region which based on the principle of partnership, prosperity, protection, independence, unity, and the values of local social cultural. The social cultural resilience of region was formed through social and cultural preservation dynamically with protecting, developing and utilizing local social cultural by tourism activities.
\end{abstract}

Keywords: Youth Participation, Community Based Tourism (CBT), Social Cultural Resilience of Region

\begin{abstract}
ABSTRAK
Arus pariwisata global mengarah pada tren baru pariwisata pedesaan dimana wisatawan datang dalam kelompok-kelompok kecil dan berinteraksi intensif, mempelajari kehidupan masyarakat dan ikut serta dalam kegiatan penduduk desa. Pariwisata model ini rentan menyebabkan perubahan sosial budaya di masyarakat jika pengelolaannya tidak direncanakan secara matang. Penelitian ini bertujuan untuk mengkaji dan merumuskan partisipasi pemuda dalam pengembangan pariwisata berbasis masyarakat (CBT) dan kontribusinya terhadap
\end{abstract}


ketahanan sosial budaya wilayah. Penelitian ini menggunakan metode deskriptif dengan prosedur metode campuran konkuren yang mengkombinasikan pendekatan kualitatif dengan kuantitatif. Penentuan sampel dipilih berdasarkan purposive sampling dengan penggunaan kriteria berdasarkan pertimbangan.

Hasil penelitian menunjukkan pemuda merupakan bagian dari aktor pengelola CBT di Desa Wisata Pentingsari (Dewi Peri). Partisipasi pemuda berada pada tingkat partisipasi citizen power dengan bobot rata-rata sebesar 70 persen. Model pengembangan CBT di Dewi Peri memungkinkan seluruh masyarakat terlibat secara aktif sebagai aktor utama. Partisipasi pemuda dalam pengembangan CBT di Dewi Peri berkontribusi terhadap ketahanan sosial budaya wilayah berdasarkan parameter asas kemitraan, kesejahteraan, perlindungan, kemandirian, kerukunan, nilai sosial dan budaya lokal. Ketahanan sosial budaya wilayah terbentuk melalui pelestarian sosial budaya secara dinamis dengan melindungi, mengembangkan dan memanfaatkan sosial-budaya lokal melalui aktivitas pariwisata.

Kata Kunci: Partisipasi Pemuda, Pariwisata Berbasis Masyarakat (CBT), Ketahanan Sosial Budaya Wilayah.

\section{PENGANTAR}

Pada abad 21, industri pariwisata disinyalir merupakan pendorong utama perekonomian yang mengantarkan puncak gelombang wisatawan ke pasar dunia. Menurut data UNWTO (Damanik, 2013: 63) 1 dari setiap 7 orang penduduk dunia melakukan aktivitas wisata ke luar batas negara asalnya. Berkorelasi dengan meningkatnya arus wisata global, kawasan ASEAN memiliki tingkat pertumbuhan jumlah wisatawan mancanegara tertinggi di dunia. Kondisi ini diproyeksi akan meningkat 10,3 persen pada tahun 2030 (UNWTO dalam Dirjen. Kerjasama ASEAN Kemenlu., 2014: 32). Seirama dengan kondisi ASEAN, jumlah wisatawan yang datang ke DIY mengalami peningkatan yang signifikan sebesar $17,9 \%$ dibanding tahun sebelumnya (Dispar. DIY dalam Kedaulatan Rakyat, 2015). Alasan kunjungan wisatawan ke Yogyakarta ini disinyalir karena daya tarik keragaman potensi alam dan budayanya. Kondisi demikian merupakan bukti bahwa budaya yang unik merupakan magnet wisata yang kuat.

Kontradiksi dengan kondisi di atas, prospek meningkatnya arus pariwisata merupakan peluang sekaligus tantangan bagi Indonesia khususnya Yogyakarta. Industri pariwisata budaya sangat rentan menyebabkan perubahan tatanan dan gaya hidup masyarakat. Pariwisata diistilahkan sebagai agen perubahan budaya (an agen of cultural change) yang mempengaruhi perjalanan orang, adat istiadat, upacara keagamaan serta cara berpikir masyarakat (Yoeti dkk, 2006: 176). Untuk itu, jika meningkatnya gelombang wisata tidak sinergis dengan perencanaan pariwisata yang matang, dikhawatirkan berdampak reaktif secara negatif terhadap kondisi sosial budaya masyarakat. Dalam konteks ini, kontribusi sumber daya manusia lokal terutama pemuda merupakan hal yang mutlak dilakukan, untuk menunjang terlaksananya pengelolaan pariwisata yang mengutamakan pelestarian budaya dan pemberdayaan masyarakat. Upaya tersebut secara simultan diharapkan mampu memberi efek domino terhadap berbagai aspek termasuk dalam mengurangi dampak negatif pariwisata.

Dampak negatif pariwisata terhadap sosial-budaya menurut United Nation (1993: 146) mengakibatkan kesenjangan sosial ekonomi, hilangnya identitas budaya, peniruan gaya hidup, serta munculnya bisnis gelap dan ilegal (prostitusi, alkohol, narkoba, dll). Oleh sebab itu, pengelolaan pariwisata diharapkan lebih berkeadilan, mengutamakan 
Gina Lestari, Armaidy Armawi, dan Muhamad -- Partisipasi Pemuda Dalam Mengembangkan Pariwisata Berbasis Masyarakat Untuk Meningkatkan Ketahanan Sosial Budaya Wilayah (Studi Di Desa Wisata Pentingsari, Umbulharjo, Cangkringan, Sleman, D.I. Yogyakarta)

kesejahteraan, konservasi dan pelestarian, sehingga dampak negatif pariwisata bisa diredam. Beberapa pakar berpandangan bahwa upaya meredam dampak negatif pariwisata ini dapat dilakukan melalui pengembangan pariwisata berbasis masyarakat (CBT) (Murphy, 1985; Timothy, 1999 dalam Tolkach, dan Brian King, 2015: 386-389). Kekayaan alam, budaya dan etnis merupakan aset yang menjadi daya tarik dan potensi untuk mengembangkan CBT di Indonesia. Oleh sebab itu, Indonesia merupakan tempat yang ideal untuk mengembangkan dan menerapkan CBT (Dhiradityakul dan John, 2013:15).

Pariwisata budaya lokal di Yogyakarta banyak dikembangkan melalui ragam wisata minat khusus di antaranya desa wisata. Wisata minat khusus, dalam hal ini desa wisata, mengarah pada daya tarik budaya lokal yang menjadi tren wisata pada jaman moderen Naisbitt dalam Ariani (2011:37) memandang kondisi tersebut sebagai paradoks global dimana semakin besar pengaruh globalisasi, semakin tinggi keinginan untuk menekuni lokalisasi, khususnya seni tradisional. Perkembangan desa wisata di Yogyakarta mengalami peningkatan sebanyak 43 desa wisata budaya dengan jumlah persebaran terbanyak berada di Kabupaten Sleman. Akan tetapi, kondisi desa wisata kategori tumbuh di Kabupaten Sleman memerlukan perhatian dan pembinaan ekstra dari segi manajemen dan sumber daya manusia. Banyak desa wisata kategori tumbuh mengalami vakum akibat salah pengelolaan serta terbatasnya manajemen dan sumber daya manusia (Dewi dalam sindonews.com, 2013). Salah satu kendala pengelolaan desa wisata berkaitan dengan upaya pengembangan dan pemberdayaan masyarakat sesuai dengan potensinya (Yogantoro dalam okezone.com,
2013). Artinya, pengembangan desa wisata tidak luput dari upaya meningkatkan dan memberdayakan sumber daya manusia lokal.

Terkait dengan hal tersebut, keterlibatan pemuda dalam pengelolaan CBT di desa wisata diharapkan mampu meningkatkan inovasi dan produktivitas pariwisata. Pemuda dilibatkan dalam pembangunan kawasan pedesaan serta diberikan akses untuk meningkatkan kemampuan dan pengalamannya. Jika upaya ini dilakukan secara berkelanjutan, peningkatan kapasitas pemuda akan sejalan dengan pembangunan masyarakat pedesaan. Melalui upaya tersebut diharapkan arus migrasi masyarakat khususnya pemuda ke kota dapat ditekan. Sejalan dengan upaya di atas, Indonesia memiliki peluang besar pembangunan dengan lebih dari 62 juta kaum muda yang mewakili 26 persen dari total penduduk (The United Nations Population Fund-UNFPA Indonesia, 2014: 12). Wacana bonus demografi Indonesia pada tahun 2030 memungkinkan sumber daya produktif berkontribusi positif terhadap pembangunan nasional.

Desa Wisata Pentingsari (Dewi Peri) dipilih sebagai lokus penelitian yang sukses dalam pengelolaan CBT dengan penghargaan Best Practise on Tourisme Ethic at Local Level dari WCTE-UNWTO (Pemerintah Kabupaten Sleman dalam http://www.slemankab.go.id, 2011). Melihat besarnya potensi dan prestasi yang dimiliki Dewi Peri, regenerasi pengelolaan desa wisata merupakan hal yang mutlak dilakukan. Untuk itu, keberlangsungan dan proses regenerasi merupakan tantangan desa wisata ke depan. Analisis tersebut memantik ketertarikan peneliti untuk merumuskan pokok permasalahan berikut: (1). Bagaimana 
partisipasi pemuda dalam pengembangan pariwisata berbasis masyarakat di Desa Wisata Pentingsari? (2). Bagaimana kontribusi partisipasi pemuda dalam pengembangan pariwisata berbasis masyarakat terhadap ketahanan sosial budaya wilayah di Desa Wisata Pentingsari?

Analisis konsep pemuda dalam penelitian memandang pemuda sebagai sumber daya potensial dan generasi penerus yang menjadi aktor kunci perubahan di masyarakat. Merujuk pada undang-undang No. 40 tahun 2009 (11) Tentang Kepemudaan, pemuda merupakan warga negara Indonesia yang memasuki periode penting pertumbuhan dan perkembangan yang berusia 16 sampai 30 tahun. Dhanani (2009: 99-100) memandang bahwa kegiatan pemberdayaan pemuda harus mengarah pada peningkatan keterampilan, pembimbingan dan berbagi (sharing) pengalaman dari pihak propesional. Terciptanya tanggung jawab, kewenangan dan hak pemuda di masyarakat secara lebih spesifik terbentuk melalui partisipasi pemuda dalam setiap upaya perubahan dan pembangunan masyarakat.

Keterlibatan pemuda dalam kerja-kerja komunal di masyarakat harus didukung oleh tersedianya akses dan keterjangkauan pemuda untuk terlibat di dalamnya. Mikkelsen (1999: 64) memandang partisipasi sebagai kontribusi sukarela, kemauan menerima dan kemampuan untuk menanggapi, keterlibatan sukarela, suatu proses yang aktif, inisiatif dan kebebasan memilih, pemantapan dialog dalam persiapan, monitoring pelaksanaan dan keterlibatan dalam pembangunan. Sementara itu, Arnstein (1969: 216-224) membagi tingkat partisipasi menjadi tiga kategori dalam gambar 1 di bawah ini.
Gambar 1

Tangga Tingkat Partisipasi Arnstein

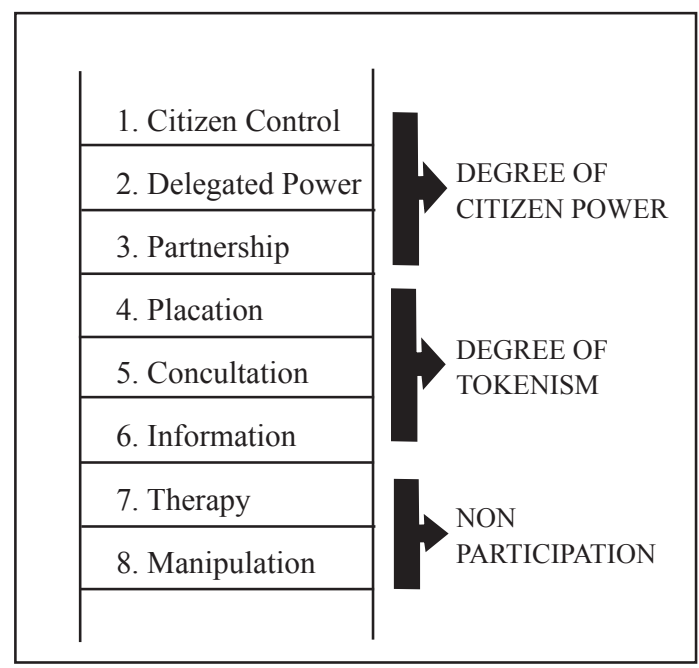

Sumber: Arnstein, Sherry, 1969

Partisipasi masyarakat merupakan ruh yang menentukan kesuksesan pengembangan CBT. Responsible Ecological Social Tour (REST) (Potjana, 2003: 12) mengemukakan CBT merupakan model pariwisata yang sistem kepemilikan dan pengelolaannya dikendalikan oleh masyarakat dengan mempertimbangkan pelestarian lingkungan, sosial dan budaya. Menurut Potjana (2003: 12), terdapat 7 prinsip dalam pengembangan Community Based Tourism (CBT) yaitu (1) mengenali, mendukung dan mempromosikan pariwisata sebagai milik masyarakat, (2) melibatkan anggota masyarakat, (3) mempromosikan keramahtamahan masyarakat, 4) meningkatkan kualitas hidup, (5) mengutamakan pelestarian lingkungan, budaya dan karakter masyarakat, (6) menghormati perbedaan budaya dan martabat manusia (cross-culture learning), serta (7) mendistribusikan manfaat secara adil kepada seluruh masyarakat.

Pengembangan desa wisata dengan model CBT (Community Based Tourism) 
Gina Lestari, Armaidy Armawi, dan Muhamad -- Partisipasi Pemuda Dalam Mengembangkan Pariwisata Berbasis Masyarakat Untuk Meningkatkan Ketahanan Sosial Budaya Wilayah (Studi Di Desa Wisata Pentingsari, Umbulharjo, Cangkringan, Sleman, D.I. Yogyakarta)

merupakan implementasi dari aspek-aspek sosial budaya yang berketahanan. VanBreda (2001:215) memandang paradigma ketahanan sosial budaya yang berkembang saat ini sebagai paradigma salutogenic. Paradigma ini mengibaratkan ketahanan sosial budaya sebagai seseorang yang sakit yang harus disembuhkan dengan upaya meningkatkan kekebalan tubuh dan menciptakan lingkungan yang memungkinkan berkembangnya ketahanan tubuh. Dalam konteks ini, ketahanan sosial budaya dibangun melalui optimalisasi potensi sosial budaya yang dimiliki. Di samping itu, dibentuk pula oleh terciptanya lingkungan sosial budaya yang mendukung terbentuknya ketahanan sosial budaya.

Konsep ketahanan sosial budaya menjadi perbincangan banyak pengamat yang menyepakati bahwa ketahanan sosial budaya memiliki tiga dimensi. Pertama, kapasitas mengatasi (coping capacities) berupa kemampuan reaktif yang memiliki daya serap untuk mengatasi hambatan. Kedua, kapasitas adaptif(adaptive capacities) berupa kemampuan untuk belajar dari pengalaman dan menyesuaikan diri dengan tantangan masa depan. Ketiga, kapasitas transformatif (transformative capacities) atau kapasitas partisipasi (participative capacities) berupa kemampuan untuk menjangkau arena sosial politik yang lebih luas. Mendorong kesejahteraan individu dan ketahanan masyarakat yang berkelanjutan terhadap krisis di masa depan (Keck dan Patrick, 2012: 11). Menurut Arauz (2010: 2) terdapat 5 keterampilan penting yang harus dimiliki generasi muda untuk membentuk ketahanan budaya pada abad 21 yaitu inovasi dan imajinasi, adaptasi dan ketangkasan, keterampilan komunikasi lintas-budaya baik inter maupun intra budaya, kemampuan analisis kritis serta kemampuan bekerja dalam tim (teamworking).

Penelitian menggunakan metode deskriptif dengan pendekatan mixed methodes atau metode campuran. Metode ini menutupi keterbatasan dan kekurangan setiap metode sehingga kekuatan penelitian menjadi lebih besar (Creswell, 2009: 4 dan 14). Strategi metode campuran yang digunakan merupakan prosedur metode campuran konkuren (concurrent mixed methods). Penentuan sampel dipilih berdasarkan purposive sampling dengan penggunaan kriteria berdasarkan pertimbangan (judgment sampling). Populasi merupakan seluruh masyarakat Dewi Peri sebanyak 356 orang yang diambil sampel berdasarkan usia muda sebanyak 65 orang atau 18 persen dari total populasi.

Teknik pengumpulan data menggunakan wawancara mendalam, kuesioner, observasi, studi dokumentasi, studi literatur dan penelusuran data online. Instrumen kuesioner menggunakan format rating scale atau skala penilaian summated ratings (Likert) dengan skala interval 0 hingga 5. Validasi data menggunakan model triangulasi dengan strategi triangulasi konkuren (concurrent triangulation strategy). Prosedur analisis data kuantitatif menggunakan teknik statistik inferensial (statistic probability) selanjutnya data kuantitatif dan kualitatif disajikan dengan data kombinasi Creswell (2009, 217-219) dan Miles \& Huberman (1992: 16-20).

\section{PEMBAHASAN}

Partisipasi Pemuda dalam Pengembangan Pariwisata Berbasis Masyarakat di Desa Wisata Pentingsari

Desa Wisata Pentingsari (Dewi Peri) terletak di lereng Gunung Merapi tepatnya 
di Dusun Pentingsari, Desa Umbulharjo, Kecamatan Cangkringan, Sleman, DIY. Dewi Peri diresmikan menjadi desa wisata pada tanggal 15 April 2008 berdasarkan Surat Keputusan Dinas Pariwisata Kabupaten Sleman Nomor 556/336 (Arsip Dewi Peri, 2010: 1). Hal ini terlihat dari pengelolaannya yang berpedoman pada visi dan misi berdasarkan asas pemberdayaan dan kesejahteraan masyarakat. Pengelolaan dilakukan oleh masyarakat termasuk pemuda di bawah koordinasi kelompok sadar wisata (Pokdarwis) Dewi Peri yang pembentukannya dilakukan secara demokratis. Pengelolaan yang berbasis keterbukaan dan pemberdayaan masyarakat tercermin dari pengelolaan dan kepengurusan di Desa Wisata Pentingsari.

Kegiatan pemilihan difasilitasi oleh panitia pencalonan (Panitia 9) yang dibentuk 1 bulan sebelum berakhirnya masa jabatan pengurus lama. Keanggotaan Panitia 9 diambil dari seluruh elemen masyarakat sebagai bentuk keterwakilan dari berbagai kelompok termasuk pemuda. Masyarakat melakukan pencoblosan sebanyak 3 kali untuk memilih ketua, sekretaris dan bendahara, sebagai pengurus inti yang diputuskan berdasarkan suara terbanyak. Kepengurusan ini berlangsung selama 2 tahun masa jabatan yang kemudian akan diadakan penggantian pengurus dengan format yang sama. Melalui proses demokrasi yang adil dan terbuka, kepengurusan yang terpilih memiliki legitimasi dan dipercaya oleh seluruh masyarakat, sehingga tugas koordinasi dan koreksi antara pengurus dan masyarakat dapat dilakukan dengan komunikasi yang komprehensif.

Pengembangan CBT di Dewi Peri merupakan model CBT tingkat satu (InWent, 2002: 3) dimana seluruh masyarakat terlibat dalam proyek pengelolaan CBT secara aktif. Untuk itu, tujuan pariwisata jenis ini lebih menekankan pada peningkatan kapasitas dan kesejahteraan masyarakat sebagai aktor lokal. Masyarakat terlibat secara aktif mulai dari perencanaan, pengelolaan, evaluasi hingga penyelesaian masalah. Setiap pengambilan kepurusan dan penyelesaian masalah dilakukan melalui rapat rutin 3 dan 6 bulanan. Penyusunan setiap paket wisata merupakan hasil pengemasan potensi desa yang masih terjaga, bukan dibuat untuk kepentingan pariwisata semata.

Pengembangan potensi produk dan daya tarik wisata di Dewi Peri memperhatikan keunikan unsur-unsur lokal baik secara fisik maupun non-fisik. Potensi fisik yang dikembangkan berupa keunikan alam dan kondisi lingkungan, keragaman sumber daya hayati, pengolahan produk lokal (kuliner), serta produk hasil kerajinan. Sementara itu, potensi non-fisik yang dikembangkan berupa adat istiadat dan keramahtamahan, cara hidup masyarakat, mitos serta kondisi sosial budaya dan sejarah lokal. Sistem pelayanan wisatawan dan aktivitas pariwisata secara teknis dilakukan oleh seluruh masyarakat Dewi Peri. Skema teknis persiapan penyambutan wisatawan di Dewi Peri dapat diuraikan pada gambar 2.

Berdasarkan skema gambar 2, aktivitas pariwisata bermula dari koordinasi langsung (tanpa perantara) antara wisatawan dengan marketing Dewi Peri. Pemesanan, pemilihan paket wisata serta jadwal kedatangan dilakukan berdasarkan kesepakatan bersama. Selanjutnya, pihak marketing Dewi Peri mengkoordinasikan teknis kegiatan wisata dengan bagian kegiatan. Bagian kegiatan mengkoordinasikan teknis penyambutan dan pelayanan wisatawan dengan semua 
Gina Lestari, Armaidy Armawi, dan Muhamad -- Partisipasi Pemuda Dalam Mengembangkan Pariwisata Berbasis Masyarakat Untuk Meningkatkan Ketahanan Sosial Budaya Wilayah (Studi Di Desa Wisata Pentingsari, Umbulharjo, Cangkringan, Sleman, D.I. Yogyakarta)

Gambar 2

Skema Teknis Pelayanan Wisatawan di Dewi Peri

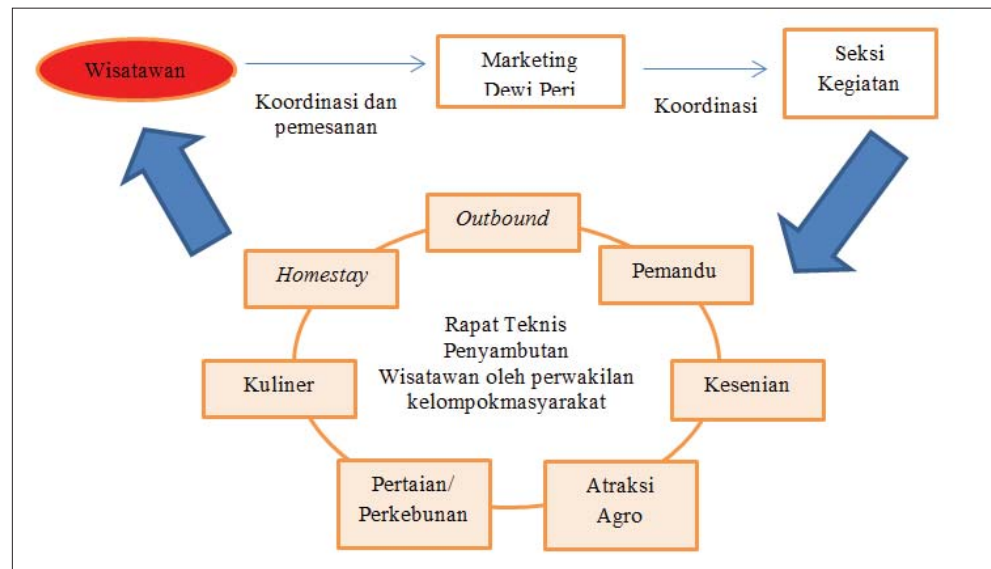

Sumber: Diolah Peneliti, 2016

Tabel 1

Faktor Pendorong Partisipasi Pemuda dalam Pengembangan CBT di Dewi Peri

\begin{tabular}{clcc}
\hline No & \multicolumn{1}{c}{ Partisipasi } & Bobot & Ket. \\
\hline 1 & Pengembangan Desa Wisata sesuai dengan aspirasi dan kebutuhan masyarakat. & 246 & Tinggi \\
2 & Mendapatkan manfaat dari adanya Dewi Peri & 250 & Tinggi \\
3 & Pengembangan Dewi Peri membantu mengatasi permasalahan hidup sehari-hari & 220 & Sedang \\
4 & Mendukung dan ikut berkewajiban mengembangkan Dewi Peri. & 260 & Tinggi \\
\hline
\end{tabular}

Sumber: Diolah Peneliti, 2016

perwakilan kelompok masyarakat melalui rapat persiapan teknis.

Dengan menerapkan teknis pembagian tugas tersebut, seluruh masyarakat termasuk pemuda ikut berpartisipasi dalam pengelolaan desa wisata. Pemasaran misalnya dilakukan baik secara langsung (keterlibatan masyarakat sebagai marketing) maupun tidak langsung (melalui getok tular). Selain itu, pengelolaan Dewi Peri didukung pula oleh terjalinnya kemitraanbaik secara internal maupun eksternal. Secara internal, Dewi Peri melakukan jejaring dengan seluruh masyarakat Dewi Peri baik secara perorangan maupun dengan kelompok masyarakat. Secara eksternal, Dewi Peri bermitra dengan desa wisata lain, pemerintah, program CSR Bank BCA, objek wisata Merapi Lava Tour dan lainnya. Berdasarkan teknis pengelolaannya, masyarakat termasuk pemuda ikut berpartisipasi dalam pengelolaan desa wisata. Adapaun partisipasi pemuda dalam mengembangkan CBT di Dewi Peri didorong oleh beberapa faktor seperti pada tabel 1 .

Berdasarkan tabel 1 tersebut, dapat disimpulkan bahwa faktor pendorong partisipasi pemuda dalam pengelolaan CBT Dewi Peri terdiri atas 4 kategori yaitu adanya organisasi yang sesuai, manfaat yang diterima, adanya komitmen yang kuat, dan pengetahuan masyarakat yang lebih baik. Berdasarkan faktor-faktor pendorong partisipasi tersebut, alasan partisipasi pemuda dapat dijelaskan pada gambar 3 .

Data pada gambar 3 menunjukkan bahwa sebagian besar pemuda (60 persen) ikut berpartisipasi dalam pengelolaan Dewi 
Gambar 3

Alasan Partisipasi Pemuda dalam Pengelolaan Dewi Peri

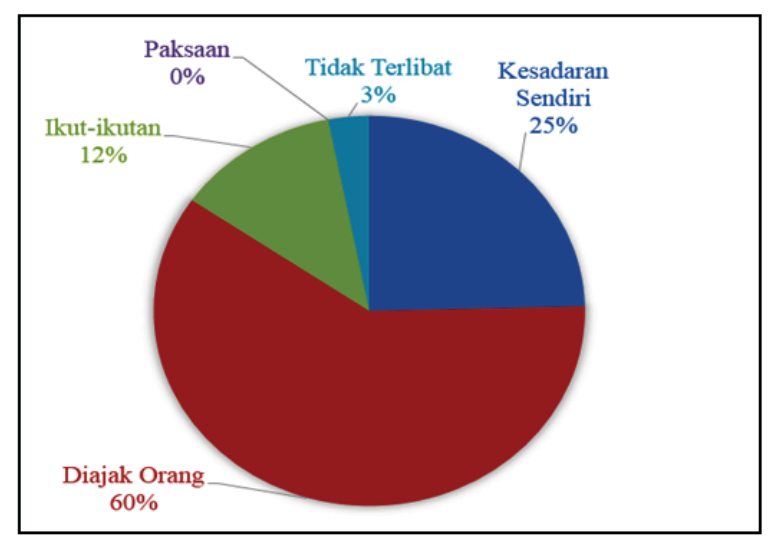

Sumber: Diolah Peneliti, 2016

Peri karena ajakan orang lain. Adapun 25 persen pemuda mengaku ikut berpartisipasi karena kesadaran sendiri, 12 persen pemuda berpartisipasi karena ikut-ikutan dan 3 persen pemuda tidak berpartisipasi. Sementara itu, tidak satupun pemuda ( 0 persen) yang ikut berpartisipasi karena paksaan atau desakan pihak lain. Berdasarkan amatan tersebut, pemuda merupakan sumber daya potensial yang menjadi kunci keberhasilan regenerasi dan keberlanjutan Dewi Peri di masa yang akan datang. Pemuda Dewi Peri memiliki karakter potensial yaitu idealisme, terbuka, spontanitas, semangat, kreatif, dan solidaritas komunal yang tinggi. Fitriyani (2015: 131) memandang bahwa idealisme dan komitmen melakukan kegiatan yang bermanfaat merupakan faktor intrinsik yang tumbuh dalam diri pemuda. Adapun organisasi kepemudaan (Ikatan Pemuda Pemudi Pentingsari-IP3) sebagai faktor ekstrinsik merupakan wakil pemuda di Dewi Peri untuk menyampaikan aspirasi, mengikuti rapat pengelolaan, menentukan kebijakan dan menyelesaikan permasalahan di Dewi Peri.
Pelibatan pemuda dalam pengelolaan CBT merupakan upaya menyiapkan bibit potensial untuk regenerasi pengurus Dewi Peri.

\section{Bentuk dan Tingkat Partisipasi Pemuda}

Bentuk partisipasi pemuda dalam pengelolaan CBT di Dewi Peri terdiri atas partisipasi uang, harta benda, tenaga dalam gotong royong, keterampilan berupa pembuatan kerajinan, tari, pemandu dan outbound serta partisipasi ide atau pendapat dan partisipasi representatif melalui perwakilan dan pemilihan. Berdasarkan hasil pengolahan data di lapangan, partisipasi tenaga dan keterampilan merupakan bobot partisipasi yang paling tinggi yaitu 78,5 persen dan 76 persen. Bobot partisipasi dalam pemilihan ketua Dewi Peri yaitu sebesar 75,4 persen. Tingkat partisipasi sedang berada pada bobot 56 persen untuk partisipasi uang, 54,5 persen untuk partisipasi ide atau gagasan dan 53,2 persen untuk partisipasi harta benda (Diolah peneliti, hasil distribusi frekuensi data kuesioner, 2016).

Tingkat partisipasi pemuda dalam mengembangkan CBT di Dewi Peri berada pada tahap kendali masyarakat (citizen control) di tingkat citizen power berdasarkan tangga tingkat partisipasi sebagaimana gambar 4.

Rata-rata bobot partisipasi pemuda pada setiap tingkat yaitu sebesar 70 persen dengan intensitas partisipasi antara kadang hingga selalu. Pada tingkat partisipasi nonparticipation, rara-rata bobot partisipasi sebesar 63 persen. Pada tingkat tokenism rata-rata bobot partisipasi pemuda sebesar 63 persen dengan taraf intensitas antara kadang hingga selalu. Pada tingkat citizen power ratarata bobot partisipasi pemuda sebesar 81,7 persen dengan taraf intensitas antara kadang hingga selalu. 
Gina Lestari, Armaidy Armawi, dan Muhamad -- Partisipasi Pemuda Dalam Mengembangkan Pariwisata Berbasis Masyarakat Untuk Meningkatkan Ketahanan Sosial Budaya Wilayah (Studi Di Desa Wisata Pentingsari, Umbulharjo, Cangkringan, Sleman, D.I. Yogyakarta)

Gambar 4

Tangga Tingkat Partisipasi Pemuda Dalam Mengembangkan CBT di

Dewi Peri

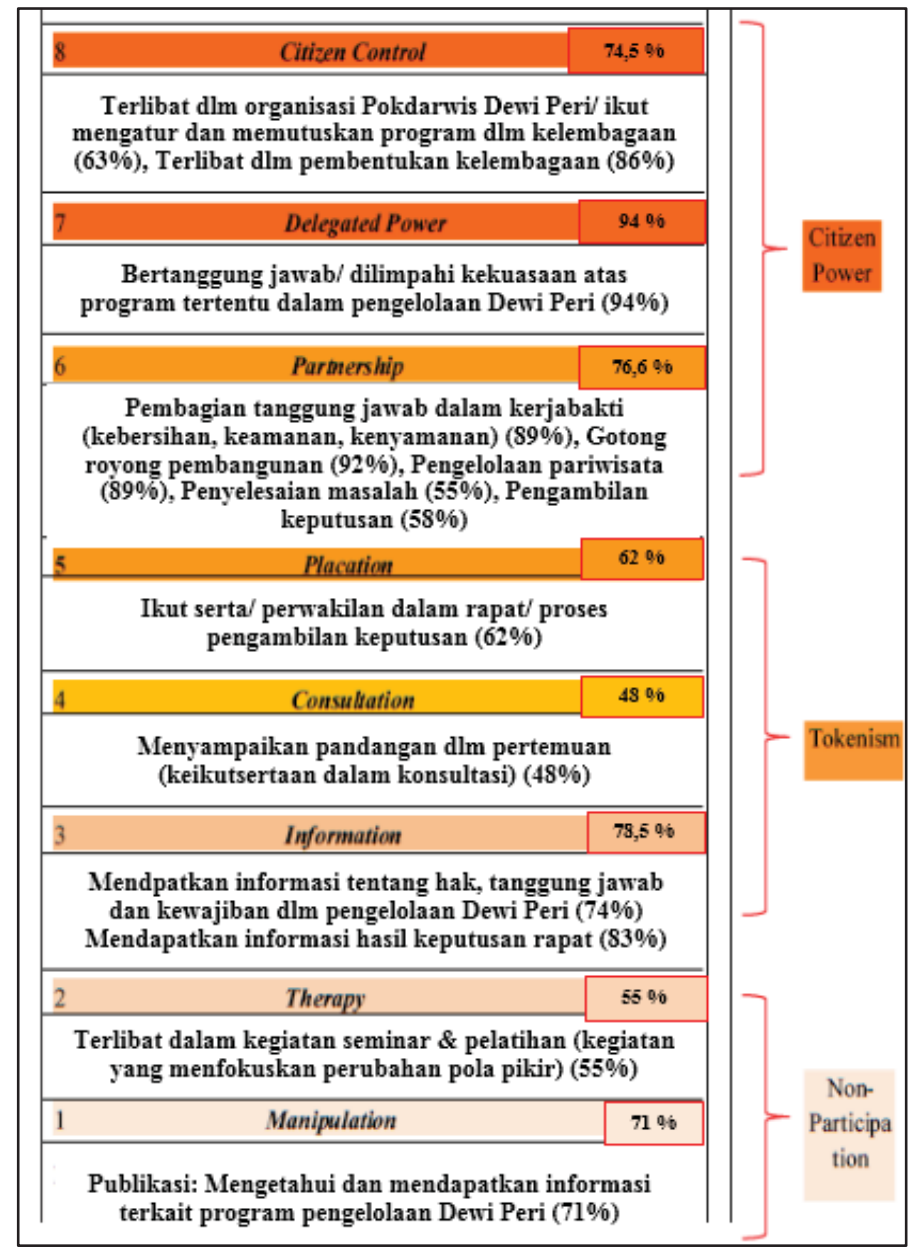

Sumber: Diolah Peneliti, 2016

Berdasarkan bobot partisipasi pada setiap tingkat di atas, partisipasi pemuda dalam pengelolaan Dewi Peri berjalan bukan tanpa hambatan. Hambatan yang muncul di antaranya berkaitan dengan kekurangan sumber daya manusia lokal terutama pemuda. Keterlibatan pemuda dalam pengelolaan Dewi Peri tidak dapat diharapkan setiap waktu. Pemuda harus mampu membagi tanggung jawab mereka antara pendidikan dengan partisipasi dalam pengelolaan Dewi Peri. Selain hambatan tersebut, terjadi kecemburuan personal karena adanya kesenjangan keterampilan dan pengalaman sebagai ego personal antar pemuda. Terjadi beberapa sentimen pribadi dengan orang tertentu yang mempengaruhi partisipasi beberapa pemuda di Dewi Peri. Sentimen pribadi ini muncul dari kalangan pemuda yang pernah menyuarakan isu ketidakadilan berkaitan dengan pembagian keuntungan dalam pembagian jadwal homestay. Berkenaan dengan masalah tersebut, perbedaan pandangan merupakan hal yang lumrah terjadi dalam kelompok masyarakat 
termasuk di Dewi Peri. Perbedaan pandangan yang terjadi antara kalangan tua dengan pemuda berkaitan dengan pengelolaan Dewi Peri secara teknis. Gagasan dan inovasi yang muncul dari kalangan muda terkadang tidak sejalan dengan pandangan kalangan tua.

Hambatan lain yang muncul dalam pengelolaan CBT berkaitan dengan permasalahan keamanan. Untuk itu, pemuda bersama dengan masyarakat melakukan ronda dan jam malam untuk menanggulangi masalah tersebut. Tidak dapat dipungkiri, kedatangan wisatawan dangan jumlah besar mengakibatkan kebisingan dan kegaduhan di Dewi Peri. Kondisi kampung yang biasanya sepi seketika menjadi ramai karena kedatangan banyak wisatawan dalam waktu yang bersamaan. Perubahan kondisi ini sempat mengakibatkan masyarakat merasa 'bukan kampung sendiri'. Banyak masyarakat yang belum memahami ketentuan daya tampung dan kualitas pelayanan dalam paket homestay kepada wisatawan. Akan tetapi, seiring berjalannya waktu, penerimaan dan kemakluman dari masyarakat sudah sangat tinggi, sehingga kedatangan wisatawan dalam jumlah besar tidak menjadi masalah bagi masyarakat. Masyarakat sudah terbiasa melayani wisatawan dengan jumlah lebih dari 500 orang serta menerima banyak manfaat positif dengan adanya kegiatan pariwisata di Dewi Peri.

Selain munculnya berbagai hambatan, masyarakat dalam hal ini pemuda banyak merasakan manfaat dari pengelolaan Dewi Peri. Keberadaan Dewi Peri banyak dirasakan manfaatnya baik secara finansial maupun nonfinansial. Secara finansial pemuda mendapat manfaat berupa kemandirian secara ekonomi, dalam arti menambah uang saku. Selain itu, mendatangkan peluang usaha bagi pemuda untuk membuka biro travel, penyewaan kendaraan, menjadi tour guide profesional dan membuka sanggar tari. Secara nonfinansial, pemuda mendapatkan manfaat berupa peningkatan kompetensi, memperluas pergaulan dan wawasan. Pengalaman memandu tamu ternyata menumbuhkan keberanian dan percaya diri, tanggung jawab dan kreatif.

\section{Kontribusinya Terhadap Ketahanan Sosial Budaya Wilayah}

Kontribusi pemuda dalam pengelolaan Dewi Peri dapat diamati dari kontribusi pemuda dalam konservasi alam dan lingkungan, pelestarian budaya (cultural sustainability), serta dalam peningkatan ketahanan sosial budaya wilayah melalui pengelolaan CBT. Pengelolaan CBT ibarat menanam bunga yang harus didukung oleh media, perawatan, dan pupuk yang sesuai. Jenis, warna, model dan bentuk pengelolaan CBT akan berbeda satu dengan yang lain tergantung potensi, model dan pengelolaannya. Berdasarkan hasil penelitian di lapangan, gambar 5 di bawah ini menunjukkan skema pengelolaan CBT di Dewi Peri.

\section{Gambar 5}

Skema Pengembangan Pariwisata Berbasis Masyarakat di Dewi Peri

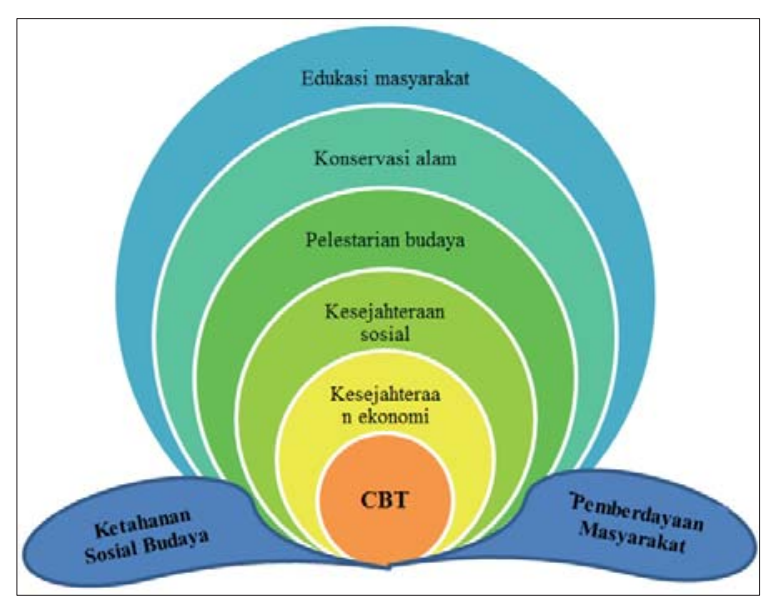

Sumber: Diolah Peneliti, 2016. 
Gina Lestari, Armaidy Armawi, dan Muhamad -- Partisipasi Pemuda Dalam Mengembangkan Pariwisata Berbasis Masyarakat Untuk Meningkatkan Ketahanan Sosial Budaya Wilayah (Studi Di Desa Wisata Pentingsari, Umbulharjo, Cangkringan, Sleman, D.I. Yogyakarta)

Berdasarkan skema pada gambar 5 tersebut, dampak positif pengelolaan CBT di DewiPerimerupakan peningkatankualitashidup masyarakat baik dalam bentuk kesejahteraan sosial maupun pembangunan ekonomi lokal. Kesejahteraan sosial terbentuk melalui terciptanya peluang pendidikan dan pelatihan bagi masyarakat, meningkatnya kesadaran hidup sehat, serta terciptanya pembangunan fisik dan non-fisik di kawasan pedesaan. Pembangunan kawasan pedesaan secara nonfisik dilakukan melalui berbagai pelatihan dan penyuluhan yang diterima masyarakat. Selain itu, dengan adanya penyuluhan dan penataan homestay, masyarakat memiliki kesadaran untuk menerapkan pola hidup sehat terutama berkaitan dengan sanitasi dan air bersih. Pembangunan kawasan pedesaan secara fisik dilakukan melalui pembangunan infrastruktur dan fasilitas desa wisata.

Masyarakat Dewi Peri terlibat secara aktif dan menerima manfaat dari proses pembangunan yang dilakukan melalui pengelolaan desa wisata. Adapun pembangunan ekonomi lokal dapat diamati dari peningkatan pendapatan masyarakat dan terciptanya lapangan pekerjaan baru. Pasar wisata yang tersedia memberikan peluang bagi masyarakat untuk terlibat sebagai aktor utama yang memiliki, mengelola dan menikmati manfaat ekonomi dari pengelolaan desa wisata. Gambar 6 menggambarkan kurva rincian pendapatan Dewi Peri.

Berdasarkan gambar 6 kurva keuangan Dewi Peri tersebut dapat diketahui bahwa total uang masuk terhitung sejak 4 Mei 2015 hingga 13 Januari 2016 sebesar Rp. 1.480.824.000. Bulan Mei dan November merupakan bulan dengan jumlah uang masuk tertinggi dimana pemasukan terbesar didominasi paket live in pelajar. Transparansi rekap keuangan Dewi Peri dipertanggungjawabkan langsung kepada seluruh masyarakat melalui rapat rutin 3 bulanan dan 6 bulanan. Persentase arus uang yang masuk di Dewi Peri sebagian besar (98 persen) diterima langsung oleh masyarakat. Hanya sekitar 2 persen atau maksimal 5 persen keuntungan masuk menjadi kas Dewi Peri. Dana kas Dewi Peri dipergunakan untuk perawatan dan pengelolaan aset serta biaya operasional Dewi Peri. Dari persentase tersebut, dapat disimpulkan bahwa

Gambar 6

Kurva Keuangan Dewi Peri Periode 2015-2017.

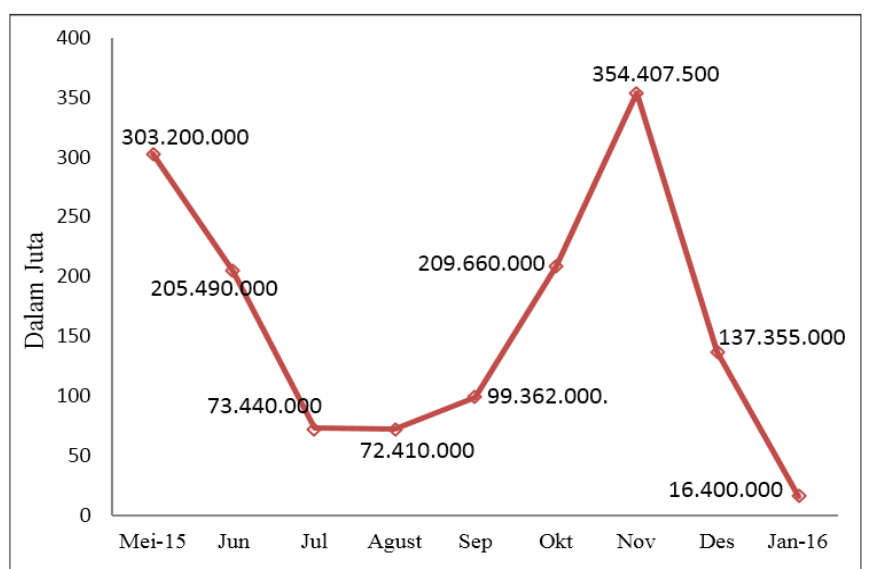

Sumber: Diolah Peneliti, 2016 
Tabel 2

Jumlah Wisatawan yang Menginap dan Kunjungan ke Dewi Peri dari 2008 (awal berdiri) hingga 2015

\begin{tabular}{|cccc|}
\hline Tahun & \multicolumn{2}{c|}{ Wisatawan } & Total \\
\cline { 2 - 3 } & Menginap & Kunjungan & \\
\hline 2008 & 591 & 613 & 1204 \\
\hline 2009 & 911 & 3.675 & 4586 \\
\hline 2010 & 4.123 & 5.873 & 9.996 \\
\hline 2011 & 6.773 & 6.342 & 13.115 \\
\hline 2012 & 10.763 & 19.943 & 30.706 \\
\hline 2013 & 12.893 & 17.774 & 30.667 \\
\hline 2014 & 6.501 & 10.883 & 17.384 \\
\hline 2015 & 10.606 & 14.732 & 25.338 \\
\hline Jumlah & $\mathbf{5 3 . 1 6 1}$ & $\mathbf{7 9 . 8 3 5}$ & $\mathbf{1 3 2 . 9 9 6}$ \\
\hline
\end{tabular}

Sumber: Diolah Peneliti, 2016.

masyarakat menerapkan asas keadilan dalam pembagian dan pendistribusian keuntungan dari pengelolaan.

Pengelolaan keuntungan desa wisata tidak terlepas dari aspek daya dukung dan daya tampung yang sesuai. Komponen ini harus dipertimbangkan tidak hanya sebagai peluang keuntungan secara ekonomi tetapi didasarkan atas pertimbangan kemanfaatan bagi masyarakat. Upaya mempertahankan keseimbangan daya dukung dan daya tampung dilakukan untuk meminimalisir dampak negatif dari membludaknya arus wisatawan. Kapasitas daya tampung Dewi Peri mencapai 700 wisatawan dengan jumlah homestay sebanyak 73 rumah. Berkaitan dengan arus wisatawan yang datang ke Dewi Peri, tabel 2 berikut ini menggambarkan jumlah wisatawan yang tercatat sejak awal berdirinya Dewi Peri hingga sekarang (2008-2015).

Jumlah wisatawan Dewi Peri mengalami rata-rata kenaikan sebanyak 4 kali lipat setiap tahunnya. Jumlah keseluruhan wisatawan yang berkunjung ke Dewi Peri dari 2008 hingga 2015 sebanyak 132.996 wisatawan. Adapun jumlah wisatawan terbanyak terjadi pada tahun 2013 yang mencapai 30.667 orang.

\section{Kontribusi Pemuda Dalam Konservasi Alam Dan Lingkungan}

Pengelolaan Dewi Peri berangkat dari landasan konsep pariwisata eco dan green yang mengutamakan pelestarian alam berwawasan lingkungan. Upaya ini mendapatkan apresiasi internasional dari UNWTO sebagai desa wisata yang menerapkan kode etik pariwisata dunia. Sistem nilai budaya tentang kesadaran penghijauan dan pelestarian lingkungan diwariskan secara turun temurun kepada generasi muda. Pemuda memiliki kesadaran untuk menerapkan budaya menanam saat menebang pohon. Selain itu, masyarakat tidak diperbolehkan menebang pohon menggunakan gergaji mesin terlebih jika ada wisatawan yang berkunjung ke Dewi Peri. Tata nilai tersebut merupakan peraturan tidak tertulis yang dipatuhi oleh seluruh masyarakat termasuk pemuda. Hampir seluruh masyarakat Dewi Peri melakukan penghijauan di pekarangan rumah dan di lingkungan dusun. Oleh karena itu, hampir sebagian besar lahan dusun merupakan lahan pekarangan dan kebun.

Nilai budaya dan kesadaran masyarakat tentang pelestarian lingkungan diadopsi dalam paket dan atraksi wisata. Paket wisata agro 
Gina Lestari, Armaidy Armawi, dan Muhamad -- Partisipasi Pemuda Dalam Mengembangkan Pariwisata Berbasis Masyarakat Untuk Meningkatkan Ketahanan Sosial Budaya Wilayah (Studi Di Desa Wisata Pentingsari, Umbulharjo, Cangkringan, Sleman, D.I. Yogyakarta)

yang dikembangkan Dewi Peri mengandung nilai edukasi terhadap penghijauan, pelestarian lingkungan dan pertanian. Paket wisata agro dilakukan berdasarkan aspek eco dan green, serta aspek edukasi bagi wisatawan. Wisatawan belajar dan mempraktekan secara langsung tata cara membajak sawah, menanam padi, menangkap ikan lele, training merawat dan memerah sapi, memetik hasil panen pertanian, praktek panen dan perawatan tanaman salak, pengolahan kopi dan training bertani jamur.

Wisatawan bersama-sama dengan masyarakat termasuk pemuda mengadakan program penghijauan dan penanaman seribu pohon di kawasan lahan kering dan lahan gambut desa. Melalui kegiatan ini, wisatawan belajar dan mempraktekan secara langsung keterampilan bercocok tanam dan tata cara perawatan tanaman. Selain itu, pemuda ikut berkontribusi sebagai pemandu regu, pemandu kegiatan dan fasilitator dalam paket dan atraksi wisata agro enterpreneur. Pemuda bertanggung jawab membimbing dan mengarahkan wisatawan selama kegiatan wisata berlangsung. Kegiatan wisata di Dewi Peri tidak berpengaruh terhadap dampak lingkungan seperti sampah, kerusakan lingkungan atau alih pungsi lahan. Masyarakat memiliki kesadaran untuk bergotong-royong menjaga kebersihan dan keasrian dusun sejalan dengan slogan Sapta Pesona (aman, tertib, bersih, sejuk, indah, ramah tamah, kenangan).

\section{Kontribusi Pemuda Dalam Pelestarian Budaya (Cultural Sustainability)}

Pengelolaan Dewi Peri dilandasi kesadaran untuk memahami, menjaga dan melestarikan warisan budaya lokal.
Masyarakat dan wisatawan bersama-sama menjaga tradisi dan norma serta nilai budaya masyarakat melalui pariwisata. Oleh sebab itu, kegiatan pariwisata Dewi Peri tidak bertentangan dengan adat istiadat dan budaya lokal, sehingga pengelolaannya menekankan pada keberlanjutan budaya di masyarakat. Analisis keberlanjutan budaya di Dewi Peri merujuk pada asas pelestarian budaya yang lebih dinamis. Upaya tersebut memberi ruang yang lebih terbuka terhadap pelestarian dengan cara pelindungan, pengembangan dan pemanfaatan budaya melalui kegiatan pariwisata. Hal ini senada dengan amanat Undang-undang Cagar Budaya (UU RI No. 11/2010) yang mencantumkan sektor pariwisata sebagai salah satu aspek dari asas kemanfaatan pelestarian budaya.

Pelindungan budaya lokal dilakukan melalui upaya menerapkan nilai-nilai budaya dalam setiap kegiatan pengelolaan CBT. Pelestarian melalui cara ini diharapkan mampu merangsang apresiasi wisatawan serta menumbuhkan rasa bangga masyarakat terhadap budayanya. Mutu budaya yang tinggi serta penghargaan masyarakat terhadap budaya akan menumbuhkan kebanggaan masyarakat terhadap budaya tersebut. Hal ini yang kemudian mentransformasi unsurunsur kebudayaan lokal menjadi identitas dari masyarakat. Dengan demikian, mutu suatu budaya merupakan identitas budaya yang melekat menjadi karakter yang dibanggakan pada suatu masyarakat.

Pengembangan budaya dalam pengelolaan CBT dilakukan melalui kreasi dan inovasi budaya dalam paket dan atraksi wisata. Potensi nilai-nilai budaya lokal dipromosikan kepada wisatawan melalui paket dan atraksi dimana wisatawan menjadi penikmat sekaligus 
pelaku wisata. Oleh karena itu, pengembangan budaya melalui aktivitas wisata di Dewi Peri merupakan upaya mempertunjukkan dan memperkenalkan (showing) budaya, bukan mengkomersilkan budaya (selling). Penentuan paket dan atraksi wisata budaya merupakan bentuk pelestarian budaya melalui eksplorasi bukan eksploitasi. Dengan demikian, kreasi dan inovasi budaya dalam paket dan atraksi wisata tetap menjaga kaidah dan ketentuan dari budaya lokal, sebagaimana ditunjukkan dalam gambar 7 .

Pemanfaatan budaya melalui aktivitas pariwisata dilakukan dengan menggali, mengenali dan menginventarisir potensi budaya lokal. Pemanfaatan ini merupakan upaya melestarikan dan memajukan budaya lokal untuk sebesar-besarnya kemakmuran masyarakat. Bentuk pemanfaatan budaya ini dilakukan melalui paket dan atraksi wisata seni dan budaya, program live in dan atraksi field trip dusun di Dewi Peri. Wisatawan diajak untuk mengenal dan mempelajari budaya secara langsung melalui paket belajar gamelan, tari tradisional, membatik, kreasi janur dan membuat wayang suket. Selain itu, seni dan budaya Jawa seperti punokawan, cokean, jatilan dan tari tradisional diperkenalkan melalui atraksi welcome dance kedatangan wisatawan.
Atraksi paket budaya lain yang menjadi daya tarik wisata yaitu tradisi kenduri lengkap dengan paket untuk makan malam. Tradisi kenduri merupakan budaya turun temurun yang diwariskan dan masih dilaksanakan oleh masyarakat Dewi Peri. Budaya dan sejarah lokal diangkat dan diperkenalkan kembali melalui paket dan atraksi wisata. Beberapa tempat yang menjadi mitos dan bukti sejarah lokal di Dewi Peri yaitu Luweng dan Watu Dakon memiliki keterkaitan dengan sejarah perjuangan kemerdekaan yang dilakukan oleh Pangeran Diponegoro. Dewi Peri juga menyimpan sejarah penyebaran agama Islam di Nusantara yang dilakukan oleh Sunan Kalijaga. Mitos dan sejarah lokal di Dewi Peri dituturkan kepada wisatawan dan generasi muda melalui paket wisata field trip.

Paket wisata live in menawarkan pengalaman yang berbeda bagi wisatawan untuk berinteraksi, mengikuti aktivitas dan hidup bersama dalam keseharian masyarakat. Paket wisata ini banyak diminati institusi pendidikan untuk menumbuhkan keterampilan dan pendidikan langsung di masyarakat. Wisatawan yang kebanyakan murid sekolah akan dititipkan kepada induk semangnya (pemilik homestay) yang bertanggung jawab sebagai orang tua asuh selama di Dewi Peri.

Gambar 7

Paket dan atraksi wisata di Dewi Peri
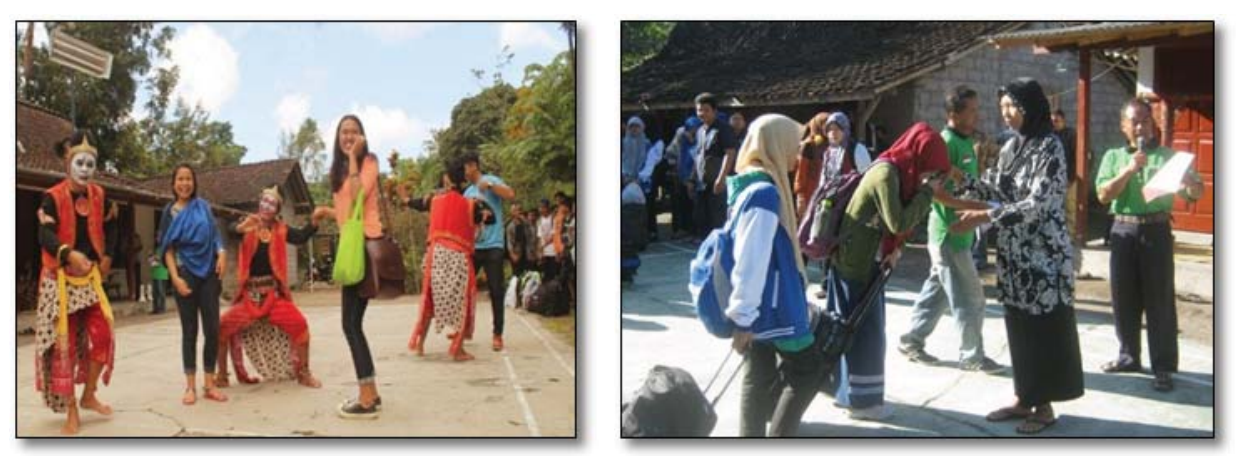

Sumber: Dokumen Peneliti, 2016. 
Gina Lestari, Armaidy Armawi, dan Muhamad -- Partisipasi Pemuda Dalam Mengembangkan Pariwisata Berbasis Masyarakat Untuk Meningkatkan Ketahanan Sosial Budaya Wilayah (Studi Di Desa Wisata Pentingsari, Umbulharjo, Cangkringan, Sleman, D.I. Yogyakarta)

Interaksi personal antara wisatawan dengan pemilik homestay (induk semang) diharapkan mampu menanamkan nilai-nilai kekeluargaan, kemandirian dan sopan santun. Wisatawan dilibatkan dalam pekerjaan-pekerjaan rumah dan berinteraksi langsung sebagai bagian dari keluarga.

Terbukanya ruang interaksi antara wisatawan dengan masyarakat dapat menjadi wahana pertukaran nilai-nilai budaya baik secara positif maupun negatif. Oleh karena itu dibutuhkan kesadaran dan penghormatan terhadap perbedaan sebagai penghalang dan penyaring (barier and filter) dari efek negatif perbedaan budaya. Interaksi yang terjalin antara masyarakat dan wisatawan sering kali menumbuhkan ikatan kekeluargaan yang erat dan berkelanjutan. Komunikasi antara wisatawan dan warga masih terjalin hingga bertahun-tahun bahkan banyak wisatawan yang kembali ke Dewi Peri untuk bersilaturahmi. Ikatan kekeluargaan yang terjalin antara wisatawan dan warga merupakan nilai luhur yang tumbuh sebagai efek positif dari pariwisata.

\section{Kontribusi Pemuda Dalam Peningkatan Ketahanan Sosial Budaya}

Kontribusi pemuda dalam peningkatan ketahanan sosial budaya di Dewi Peri mengarah pada aspek-aspek sosial budaya pada setiap unsur pengelolaan CBT. Aspek yang dianalisis untuk mengetahui kondisi ketahanan sosial budaya di Dewi Peri yaitu paradigma ketahanan sosial budaya, dimensi, kompetensi dan faktor yang mempengaruhi parameter kesuksesan (positif outcome) ketahanan sosial budaya. Berdasarkan hasil penelitian di lapangan, siklus peningkatan ketahanan sosial budaya melalui pengelolaan CBT di Dewi Peri dapat dilihat pada gambar 8 .

Analisis ketahanan sosial budaya dalam penelitian menggunakan paradigram salutogenic (VanBreda, 2001: 215) yang memandang upaya mengebalkan, optimalisasi potensi serta menciptakan lingkungan yang

Gambar 8

Siklus Peningkatan Ketahanan Sosial Budaya Melalui Pengelolaan CBT di Dewi Peri

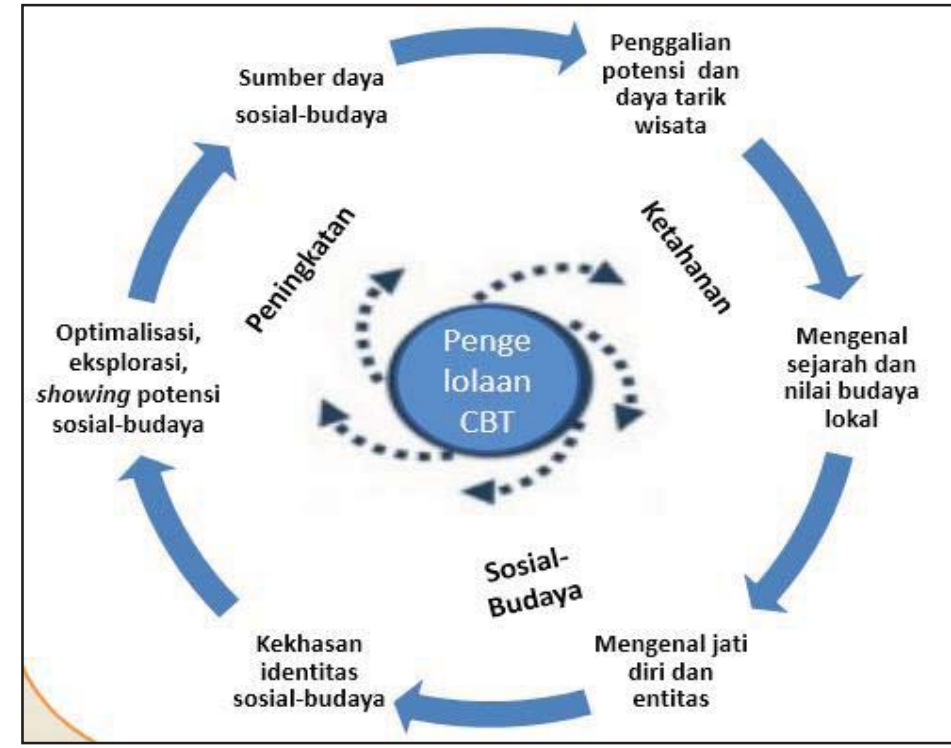

Sumber: Diolah Peneliti, 2016. 
mendukung terbentuknya ketahanan budaya. Kekebalan budaya yang terbentuk dalam pengelolaan CBT terlihat dari eksistensi dan keaslian budaya yang terjaga. Masyarakat memahami dan mempertahankan keaslian budaya lokal yang unik dan khas melalui pengelolaan pariwisata. Optimalisasi potensi budaya dalam pengelolaan CBT dilakukan melalui penggalian identitas dan potensi budaya lokal. Oleh sebab itu, optimalisasi potensi yang dilakukan melalui paket atraksi budaya tidak bermakna eksploitasi budaya tetapi bermakna eksplorasi budaya.

Paradigma dalam pembentukan ketahanan sosial dilakukan melalui upaya mengenali jati diri dan nilai budaya lokal. Selain itu, didukung pula oleh optimalisasi sumber daya sosial dan pemanfaatkan potensi sosial masyarakat. Seorang individu harus mengetahui asalusulnya untuk mengenali dirinya. Untuk mengetahui asal-usulnya, seorang individu harus mengetahui sejarah dan budaya yang menjiwai jati diri dan entitasnya. Melalui aktivitas pariwisata, pemuda dikenalkan dengan sejarah dan budaya lokal sebagai identitas masyarakat Dewi Peri. Adapun dimensi ketahanan sosial budaya yang terbentuk dalam pengelolaan CBT di Dewi Peri terdiri atas perlindungan sosial terhadap masyarakat, partisipasi masyarakat dan pemeliharaan kearifan lokal. Perlindungan sosial yang terbentuk berupa peningkatan ekonomi yang berkontribusi langsung terhadap kesejahteraan masyarakat. Partisipasi aktif dalam kegiatan sosial termasuk pengelolaan CBT terbukti mampu melestarikan nilai budaya rukun di masyarakat.

Pemeliharaan kearifan lokal berjalan beriringan dengan aktivitas pariwisata dan upaya pelestarian budaya. Kondisi lestarinya budaya lokal di Dewi Peri dapat dianalisis berdasarkan indikator kelestarian budaya yang terdiri atas eksistensi budaya, berkembangnya ragam budaya dan nilai tambah budaya. Eksistensi budaya lokal di Dewi Peri terlihat dari dipeliharanya nilai-nilai budaya. Nilai budaya ini berupa adat istiadat, sopan santun, kearifan lokal, tradisi dan daur hidup serta bentuk budaya non-bendawi lainnya. Eksistensi bentuk budaya bendawi yang masih dipelihara melalui pengelolaan CBT yaitu wayang suket, batik, janur dan pengolahan kuliner tradisional.

Kompetensi ketahanan sosial budaya dalam penelitian ini merupakan indikator keterampilan yang harus dimiliki pemuda. Indikator tersebut yaitu inovasi dan kreativitas, ketangkasan, komunikasi lintas budaya, kemampuan analisis kritis, kemampuan kerja team, kapasitas mengatasi permasalahan (coping capacities), kapasitas adaptasi (adaptive capacities) dan kapasitas transformasi (transformative capacities). Inovasi dan kreativitas merupakan salah satu karakter pemuda Dewi Peri secara umum. Keterampilan komunikasi lintas budaya diperoleh melalui interaksi secara langsung dengan wisatawan dari berbagai daerah. Adapun kemampuan kerja team dan ketangkasan pemuda tumbuh dan terlatih melalui pembagian tugas dan tanggung jawab yang diamanahkan kepada pemuda.

Keterlibatan pemuda dalam penyusunan, pengelolaan, pengambilan keputusan hingga penyelesaian masalah yang terjadi di Dewi Peri mampu menumbuhkan kemampuan analisis kritis dan kemampuan kerja team bagi pemuda. Gagasan kritis yang muncul dari kalangan pemuda menjadi masukan dan koreksi untuk kesuksesan desa wisata. Selain itu, masyarakat mengakui kemampuan kerja team pemuda 
Gina Lestari, Armaidy Armawi, dan Muhamad -- Partisipasi Pemuda Dalam Mengembangkan Pariwisata Berbasis Masyarakat Untuk Meningkatkan Ketahanan Sosial Budaya Wilayah (Studi Di Desa Wisata Pentingsari, Umbulharjo, Cangkringan, Sleman, D.I. Yogyakarta)

dengan mempercayakan pengelolaan aset dusun dan koordinasi paket wisata outbound kepada pemuda. Keterampilan pemuda dalam mengatasi permasalahan (coping capacities) dapat dianalisis dari keterlibatan pemuda dalam penyelesaian masalah melalui musyawarah mufakat. Pemuda Dewi Peri mampu menangkal dan membatasi diri dari dampak negatif pariwisata. Perbedaan budaya dengan wisatawan tidak membawa pengaruh buruk terhadap cara berpakaian, pergaulan, gaya bahasa dan pola interaksi pemuda.

Kapasitas adaptif (adaptive capacities) pemuda terlihat dari kemampuan pemuda menyesuaikan diri dengan perubahan, menangkap peluang dari tantangan gelombang wisata di Dewi Peri. Kapasitas transformatif pemuda di Dewi Peri merupakan kemampuan pemuda untuk berubah kearah yang lebih positif. Pemuda memiliki kemauan dan kemampuan untuk belajar, meningkatkan potensi dan keterampilan melalui berbagai pelatihan dan penyuluhan. Pelbagai kapasitas yang dimiliki pemuda tersebut merupakan modal bagi peningkatan ketahanan sosial budaya di masyarakat Dewi Peri.

Faktor yang mempengaruhi ketahanan sosial budaya di Dewi Peri terdiri atas pengaruh tradisi, pendidikan, kepemimpinan, kepribadian dan identitas masyarakat. Tradisi masyarakt Dewi Peri terbentuk dari dinamika sistem nilai dan norma sosial masyarakat agraris komunal pedesaan. Tradisi dan kebudayaan masyarakat Dewi Peri diangkat menjadi potensi dan daya tarik wisata. Penentuan daya tarik wisata ini berangkat dari penggalian potensi dusun serta identitas dan kepribadian masyarakat. Dengan demikian, desa wisata menjadi wahana bagi pengenalan dan pelestarian budaya masyarakat.
Pendidikan keluarga tentang kesopanan, tatakrama dan karakter yang baik merupakan faktor yang tidak kalah penting. Masyarakat menyadari pentingnya pelestarian tradisi dan nilai-nilai budaya yang positif. Oleh karena itu, pendidikan keluarga yang diterapkan tidak terlepas dari pewarisan nilai-nilai budaya lokal. Selain faktor di atas, kesadaran tokoh masyarakat untuk mengembangkan potensi sosial budaya merupakan salah satu faktor yang berpengaruh terhadap pembentukan ketahanan sosial budaya di Dewi Peri.

Parameter kesuksesan ketahanan sosial budaya di Dewi Peri dapat diamati dari terbentuknya kesejahteraan masyarakat. Kesejahteraan masyarakat ini diukur dari meningkatnya keberdayaan ekonomi dan keterampilan sebagai kualitas hidup masyarakat. Parameter lain dari meningkatnya ketahanan sosial budaya yaitu keberdayaan masyarakat. Pengelolaan CBT di Dewi Peri terbukti memberdayakan masyarakat secara mandiri. Masyarakat memiliki kesadaran untuk terlibat, menyumbangkan harta, tenaga, waktu dan pikiran mereka untuk mengelola desa wisata. Pengelolaan desa wisata juga merupakan investasi lestarinya kondisi sosial dan budaya lokal. Adapun aspek kesetaraan ditunjukkan melalui keterbukaan dan demokrasi dalam pembentukan pengurus Dewi Peri. Masyarakat memiliki hak yang sama untuk memilih dan dipilih menjadi pengurus inti Pokdarwis Dewi Peri.

Pengembangan CBT merupakan seni dan strategi pemberdayaan masyarakat melalui pariwisata yang mempertimbangkan aspek kesejahteraan masyarakat, pelestarian budaya dan konservasi lingkungan. Dengan demikian, pada intinya parameter kesuksesan pengelolaan CBT yaitu terbentuknya sosial 
budaya masyarakat yang berketahanan. Ketahanan sosial budaya berkait erat dengan kemampuan masyarakat memelihara kearifan lokal dan sumber daya sosial. Nilai budaya yang diangkat dan dilestarikan melalui aktivitas pariwisata merupakan sikap mental yang menggambarkan kepribadian dan identitas masyarakat. Kepribadian masyarakat ini merupakan modal untuk meningkatkan ketahanan sosial budaya di Dewi Peri. Wujud ketahanan sosial budaya di Dewi Peri dapat dilihat dari kondisi sistem gotong royong masyarakat, lestarinya seni dan budaya masyarakat serta terpeliharanya tradisi daur hidup dan upacara perayaan masyarakat.

Pada intinya nilai budaya gotong royong merupakan modal utama pengelolaan CBT di Dewi Peri. Pariwisata berbasis masyarakat (CBT) hanya akan terwujud dalam sistem masyarakat yang partisipatif dengan modal sosial yang masih tinggi. Masyarakat Dewi Peri terbiasa melakukan berbagai kegiatan sosial masyarakat secara gotong royong termasuk dalam pengelolaan desa wisata. Selain itu, masyarakat Dewi Peri masih melestarikan upacara daur hidup berdasarkan kebudayaan Jawa. Upacara daur hidup tersebut dipertahankan dan diwariskan secara turun temurun kepada generasi selanjutnya.

Masyarakat Dewi Peri masih melaksanakan serangkaian upacara kelahiran, tradisi manten hingga upacara kematian sebagai rangkaian terakhir dari upacara daur hidup manusia. Rangkaian upacara daur hidup tersebut digelar melalui tradisi kenduri sebagai ucapan syukur dan doa atas serangkaian perjalanan hidup yang terjadi. Selain tradisi kenduri daur hidup masyarakat, tradisi kenduri juga dilaksanakan untuk syukuran dusun. Upacara kenduri saparan atau merti dusun (bersih desa), tradisi kenduri ruwahan, kenduri suroan dan kenduri muharam dan kenduri menjelang hari raya lebaran. Selain itu, masyarakat masih mempertahankan tradisi jimpitan atau membayar sejumlah uang untuk kepentingan bersama secara suka rela.

Kesenian sebagai salah satu dari wujud budaya membutuhkan media dan apresiasi untuk tetap eksis dan lestari. Dengan demikian, aktivitas wisata di Dewi Peri merupakan salah satu sarana pendukung bagi masyarakat untuk nguri-uri kesenian dan budaya lokal. Kesenian yang masih dipelihara masyarakat Dewi Peri di antaranya yaitu kesenian kuda lumping, angguk, sholawatan, tari Jawa, baik tari klasik maupun tari kreasi baru, karawitan, cokekan, batik dan wayang suket. Kesenian lain yang masih dilestarikan oleh masyarakat yaitu gejok lesung, salah satu kesenian tradisional dari Yogyakarta yang terancam punah. Gejog lesung merupakan atraksi tradisi memukul lesung kayu dengan alu atau pemukul dari kayu sebagai bentuk ucapan syukur kepada Dewi Sri (Dewi Padi) atas melimpahnya hasil panen.

\section{SIMPULAN}

Berdasar uraian tersebut di atas dapat ditarik simpulan sebagai berikut.

Pertama, masyarakat termasuk pemuda merupakan aktor utama pengelola CBT di Dewi Peri. Bentuk partisipasi pemuda dalam mengembangkan CBT di Dewi Peri yaitu tenaga, harta benda, ide dan gagasan, uang, partisipasi sosial, partisipasi $\mathrm{dlm}$ proses pengambilan keputusan serta partisipasi refresentatif. Adapun tingkat partisipasi pemuda dalam mengembangkan CBT di Dewi Peri berada pada tingkat citizen power dengan rata-rata bobot persentase setiap tingkat 
Gina Lestari, Armaidy Armawi, dan Muhamad -- Partisipasi Pemuda Dalam Mengembangkan Pariwisata Berbasis Masyarakat Untuk Meningkatkan Ketahanan Sosial Budaya Wilayah (Studi Di Desa Wisata Pentingsari, Umbulharjo, Cangkringan, Sleman, D.I. Yogyakarta)

sebesar 70 persen. Artinya, kadar frekuensi partisipasi pemuda berada pada bobot yang baik.

Kedua, kontribusi pemuda dalam mewujudkan pengelolaan CBT yang sukses dianalisis berdasarkan telaah teori dan hasil temuan peneliti. Beberapa prinsip kesuksesan CBT yang terdapat dalam pengelolaan Dewi Peri yaitu (1) dampak positif bagi masyarakat lokal, (2) distribusi keuntungan secara adil, (3) daya dukung dan daya tampung yang seimbang, (4) konservasi alam dan lingkungan (eco dan green konsep), (5) pelestarian budaya, (6) aspek edukasi dan menghormati perbedaan budaya (cross culture learning). Kontribusi pemuda dalam meningkatkan ketahanan sosial budaya dianalisis berdasarkan paradigma dimensi, kompetensi dan faktor yang mempengaruhi pengembangan ketahanan sosial budaya di Dewi Peri. Sementara itu, wujud ketahanan sosial budaya dapat diamati dalam sistem gotong royong masyarakat, pelestarian tradisi daur hidup, peringatan upacara peringatan dan perayaan masyarakat, serta seni dan budaya yang berkembang di masyarakat.

Berdasarkan hasil penelitian dan temuan di lapangan, peneliti merekomendasikan halhal sebagai berikut.

Pertama, pengembangan CBT di Dewi Peri hendaknya dijadikan percontohan (rule model) pengembangan pariwisata yang berketahanan sosial buadaya dengan mempertimbangkan pemberdayaan dan kesejahteraan masyarakat, pelestarian sosial budaya dan konservasi alam.

Kedua, dibutuhkan forum pertemuan khusus untuk pemuda pada tingkat regional ASEAN berkaitan dengan pengembangan pariwisata berbasis masyarakat (CBT), dengan melibatkan akademisi, praktisi, organisasi maupun bisnis pendukung, sebagai media bertukar pengalaman dan pengetahuan. Hal ini direkomendasikan mengingat kawasan ASEAN memiliki peluang pengembangan pariwisata dengan kekayaan sumber daya alam dan budaya yang melimpah, meningkatnya potensi arus wisata keASEAN, dan pengelolaan pariwisata melalui model CBT belum menjadi isu bersama bagi beberapa negara di kawasan ASEAN.

\section{DAFTAR PUSTAKA}

Arauz, Juancarlos, 2010, Youth Training Events Public Symposia Cultural-Resilience: Cultural Resilience: 5 Essential $21^{\text {st }}$ Century Competencies pp. 1-2 (internet), E3ed-Education-Excellence-Equality, $<$ http://www.extension.umn.edu> (diakses 31 Desember 2015).

Ariani, Ni Made, 2011, Pergulatan Otentisitas dan Komodifikasi dalam Pariwisata Budaya, Jurnal Analisis Pariwisata, Vol. 11, No. 1, hal 27-40.

Arnstein, Sherry R, 1969, A Ladder of Citizen Participation, Journal of the American Planning Association, Volume 35, No 4. Arsip Dewi Peri, 2010

Creswell, John W., 2009, Research Design: Qualitative, Quantitative and Mixed Methodes Approaches (Third Edition), Lost Angeles, SAGE Publications.

Damanik, Janianton, 2013, Pariwisata Indonesia: Antara Peluang dan Tantangan, Yogyakarta, Pustaka Pelajar.

Dewi, Shavitri, N. 2013, 26 Persen Desa Wisata Sleman Vakum (internet) sindonews. com, http://ekbis.sindonews.com/ read/765213/34/26-persen-desa-wisatasleman-vakum-1374738832 (diakses 9 November 2015). 
Dhanani, S., Islam, I. \& Anis Chowdhury, A., 2009, The Indonesian Labour Market: Changes and Challenges, London, Routledge.

Dhiradityakul, Kris \& John Hummel, 2013, Community Based Tourism in ASEAN-An Overview Per Country, dalam Innovating CBT in ASEAN: Current Directions and New Horizons, Diedit oleh John Hummel, Hugo de Jong dan Kris Dhiradityakul, Thailand, Thailand Community Based Tourism Institute (CBT-I).

Direktorat Jenderal Kerjasama ASEAN Kementrian Luar Negeri, 2014, Buletin Komunitas ASEAN - Potensi Pasar ASEAN: Geliat Sektor Pariwisata ASEAN, Jakarta, Buletin Publikasi Direktorat Jenderal Kerja Sama ASEAN Kementerian Luar Negeri, Edisi-4.

Fitriyani, 2015, Peran Pemuda dalam Mengembangkan Eco Edu Wisata Mangrove dan Implementasinya Terhadap Ketahanan Lingkungan Daerah, Jurnal Ketahanan Nasional, Volume 21, No. 2, hal 128-141.

InWent, 2002, Internationale Weiterbildung und Entwicklung gGmbH, Training Manual for Community Based Tourism, Germany: CDG-ZEL (Environment and Resources Protection - Center for Food, Rural Development and the Environment): Addendum to "The Ecotourism Training Manual for Protected Area Managers.

Keck, Markus dan Patrick Sakdapolrak, 2012, What Is Social Resilience? Lessons Learned and Ways Forward, Erdkunde (internet), Mart, 67 (1) hal 5-19. < http:// www.jstor.org $>$ (diakses 25 September 2015).

Kedaulatan Rakyat, 2015, Dinas Pariwisata DIY: Kunjungan Wisatawan 2014
Lampaui Target (internet), Kedaulatan Rakyat, <http://krjogja.com/read/247646/ kunjungan-wisatawan-2014-lampauitarget. $k r>$ (diakses 1 Juni 2015).

Mikkelsen, Britha. (1999). Metode Penelitian Partisipatoris dan Upaya-upaya Pemberdayaan: sebuah buku pegangan bagi para praktisi lapangan. Jakarta, Yayasan Obor Indonesia.

Miles, Matthew B. \& Huberman A. Michael, 1992, Analisis Data Kualitatif, Jakarta, Universitas Indonesia Press.

Pemerintah Kabupaten Sleman, 2011, Data Prestasi Kabupaten Sleman 2011 (internet), Pariwisata <http://www.slemankab.go.id> (diakses 9 Oktober 2015).

Potjana, Suansri, 2013, Introduction, dalam Innovating CBT in ASEAN: Current Directions and New Horizons, Diedit oleh John Hummel, Hugo de Jong dan Kris Dhiradityakul, Thailand, Thailand Community Based Tourism Institute (CBT-I).

Potjana, Suansri, 2003, Community Based Tourism Handbook, Thailand, Responsible Ecological Social Tour-REST, Mild Publishing.

Tolkach, Denis dan Brian King, 2015, Strengthening Community-Based Tourism in a new resource-based island nation: Why and how?, Tourism Management (internet), January, 48 hal. 386-398. $<w w w . e l s e v i e r . c o m / l o c a t e / t o u r m a n>$ (diakses 5 Desember 2015)

UNFPA Indonesia, 2014, Monograph Series: Youth in Indonesia, Jakarta, UNFPA Indonesia.

United Nation, 1993, Management of Sustainable Tourism Development: Escap Tourism Review No.11, Bangkok, 
Gina Lestari, Armaidy Armawi, dan Muhamad -- Partisipasi Pemuda Dalam Mengembangkan Pariwisata Berbasis Masyarakat Untuk Meningkatkan Ketahanan Sosial Budaya Wilayah (Studi Di Desa Wisata Pentingsari, Umbulharjo, Cangkringan, Sleman, D.I. Yogyakarta)

Economic and Social Commission for Asia and The Pacific.

VanBreda, Adrian DuPlessis, 2001, Resilience Theory: A Literature Review- Chapter Seven: Cross-Cultural Perspectives on Resilience, South African Military Health Service, Military Psychological Institute, Social Work Research \& Development, October 2001, hal 215-218.

Yoeti, H. Oka A. dkk, 2006, Pariwisata Budaya: Masalah dan Solusinya, Jakarta, PT. Pradnya Paramita.
Yogantoro, Doto, 2013, Nilai Lokal Kurang Digali, Desa Wisata Sleman Stagnan (internet) okezone.com, http://lifestyle.okezone. com/read/2013/11/25/407/902139/nilailokal-kurang-digali-desa-wisata-slemanstagnan (diakses 9 November 2015).

\section{Peraturan Perundangan}

Undang-Undang No. 40 Tahun 2009 Tentang Kepemudaan

Undang-Undang RI No. 11 Tahun 2010 Tentang Cagar Budaya 